\title{
ANALISIS SISTEM PENCATATAN AKUNTANSI PADA USAHA MIKRO KECIL DAN MENENGAH KOTA BAUBAU
}

\author{
Muhammad Rais R. \\ Program Studi Akuntansi, Fakultas Ekonomi \\ Universitas Muhammadiyah Buton, Baubau, Indonesia \\ e-mail: raismuhamad000@gmail.com
}

\begin{abstract}
ABSTRAK
Penelitian ini bertujuan untuk mengetahui sistem pencatatan akuntansi pada usaha mikro, kecil dan menengah di kota Baubau. Metode pengumpulan data yang digunakan adalah penelitian lapangan (field research) dan penelitian kepustakaan (library research). Metode analisis data yang digunakan adalah deskriptif kualitatif.

Berdasarkan hasil analisis data yang dikumpulkan maka dapat diambil kesimpulan bahwa Toko Mira dan Bordir DYX sebenarnya sudah menerapkan akuntansi secara sederhana seperti melakukan pencatatan penjualan, pembelian, persediaan, kas masuk, kas keluar, biaya gaji dan biaya lain-lain. Namun akuntansi yang diterapkan belum optimal, yaitu dari membuat pencatatan sampai dengan pelaporan. Hal ini disebabkan oleh beberapa faktor kendala yang dihadapi yaitu: (1) minimnya pengetahuan tentang pencatatan akuntansi dan (2)Kurangnya kesadaran terhadap pentingnya akuntansi terbukti dari rendahnya tingkat kebutuhan akuntansi.
\end{abstract}

Kata Kunci : Sistem Pencatatan Akuntansi, Usaha Mikro Kecil dan Menengah

\section{ABSTRACT}

This study aims to determine the Accounting Recording System on micro, small and medium enterprises in Baubau city. Data collection methods used are field research (field research) and research literature (library research). Data analysis method used is Descriptive Qualitative.

Based on the research that the authors do, it can be concluded that Mira Shop and DYX Embroidery actually have applied a simple accounting such as recording sales, purchases, inventory, cash entry, cash out, salary costs and other expenses. But the accounting applied is not optimal, ie from making the recording up to the reporting. This is caused by several obstacles faced are: 1 . The lack of knowledge about accounting records. 2. Lack of awareness of the importance of accounting is evident from the low level of accounting needs.

Keywords : Accounting Recording System, Micro Small and Medium Enterprises.

\section{PENDAHULUAN}

Usaha Mikro, Kecil dan Menengah secara langsung mendorong pertumbuhan ekonomi untuk masyarakat menengah ke bawah. Kegiatan-kegiatan ekonomi dari Usaha Mikro, Kecil dan Menengah telah membuka lapangan kerja baru bagi masyarakat Indonesia sehingga dapat menyerap tenaga kerja Indonesia yang masih menganggur. Penyerapan tenaga kerja baru oleh Usaha Mikro, Kecil dan Menengah akan berdampak secara signifikan dalam menurunkan tingkat pengangguran masyarakat Indonesia. 
Usaha Mikro, Kecil dan Menengah juga memberikan kontribusi bagi Indonesia dari segi makro ekonomi. Pendapatan Domestik Bruto Indonesia yang dihasilkan dari kegiatan Usaha Mikro, Kecil dan Menengah mencapai 57,12\%. Berdasarkan data Kementerian Koperasi dan Usaha Kecil Menengah tahun 2013, jumlah unit Usaha Mikro, Kecil dan Menengah (UMKM) mencapai 55,2 juta unit atau 99,98\% terhadap total unit usaha di Indonesia. Tenaga kerja yang terlibat didalamnya mencapai 101,72 juta orang atau sekitar 97,3\% dari total seluruh tenaga kerja diIndonesia. Perkembangan Usaha kecil dan Menengah dari tahun ke tahun selalu menunjukkan tren pertumbuhan yang signifikan dan tercatat rata pertumbuhan sekitar 8\% pertahun pada tahun2005 sampai 2008.

Berdasarkan data dari Kementerian Koperasi dan Usaha Kecil Menengah yang telah diuraikan diatas, Usaha Mikro, Kecil dan Menengah dapat menjadi ujung tombak pembangunan ekonomi nasional di Indonesia. Hal itu terjadi karena Usaha Mikro, Kecil dan Menengah bersentuhan langsung dengan masyarakat yang berada di sekitarnya dan menggerakkan perekonomian kerakyatan.

Usaha Mikro, Kecil dan Menengah menggerakkan sector riil, karena UMKM lebih berfokus pada pengembangan industry rumah tangga dan mendorong factor produksi dan konsumsi. Sektor riil ini menghasilkan barang serta jasa yang dapat dinikmati baik secara langsung maupun tidak langsung.

Pengembangan secara berkelanjutan dari Usaha Mikro, Kecil dan Menengah dinilai dapat menjaga perekonomian Indonesia dari kemungkinan terjadinya krisis ekonomi seperti tahun 1998 atau tahun 2008. Usaha Mikro, Kecil dan Menengah relatif jarang menggunakan hutang perbankan, menggunakan mata uang rupiah, dan tidak atau belum berhubungan dengan pihak asing, sehingga terjadinya krisis ekonomi tahun 1998 dan 2008 tidak mempengaruhi usaha mikro, kecil dan menengah secara signifikan (Kompas,6April2013). Berdasarkan dari artikel ekonomi tersebut, jika produk hasil industri lokal dapat merajai pasar domestik, kondisi ekonomi bangsa akan jauh lebih stabil dan cenderung kuat saat Negara lain mengalami krisis.

Walaupun perkembangan UMKM meningkat, namun masih terdapat masalah dalam pengelolaan dana dan pencatatan akuntansi yang baik. Masalah seputar UMKM di Indonesia menurut penelitian yaitu mengenai permodalan yang kecil sehingga sulit memenuhi pesanan, sulit mendapatkan kredit dari bank, kurang mampu mengadakan pencatatan dan pelaporan yaitu tidak mampu membuat neraca dan laporan laba-rugi serta tercampurnya antara keuangan perusahaan dengan keluarga. [1] 
Dengan akuntansi yang memadai yang menghasilkan laporan keuangan, maka UMKM dapat memenuhi persyaratan dalam pengajuan kredit, mengevaluasi kinerja, mengetahui posisi keuangan dan menghitung pajak [2]. Hal ini bisa dilakukan jika unit usaha melakukan sistem akuntansi yang disesuaikan dengan jenis usahanya. Jika perusahaan belum mampu untuk menciptakan sistem akuntansi yang baik, minimal unit usaha (kecil dan menengah) melakukan sistem pembukuan yang baik.

Proses akuntansi akan menghasilkan informasi bagi pihak-pihak yang berkepentingan untuk pengambilan keputusan mengenai aktivitas dan kondisi perusahaan. Bagi kreditur, informasi akuntansi digunakan untuk keamanan dana yang dipinjamkannya dan tingkat penghasilan yang akan diperolehnya. Bagi manajemen, akuntansi memiliki peranan penting yaitu dalam hal melindungi harta perusahaan, penyusunan rencana kegiatan perusahaan di masa yang akan datang, pengukuran penghasilan perusahaan dalam kurun waktu tertentu dan pengawasan kegiatan perusahaan. Bagi investor, informasi akuntansi digunakan sebagai tolok ukur tingkat keuntungan yang akan diperolehnya jika ia membeli saham perusahaan tertentu [3].

Informasi akuntansi berhubungan dengan data akuntansi atas transaksitransaksi keuangan dari suatu unit usaha, baik usaha jasa, dagang maupun manufaktur. Agar informasi akuntansi dapat dimanfaatkan oleh manajer atau pemilik usaha, maka informasi tersebut disusun dalam bentuk-bentuk yang sesuai dengan Standar Akuntansi Keuangan [4].

Penerapan akuntansi dalam UMKM sangat diperlukan karena digunakan untuk mengetahui pencatatan dan pelaporan keuangan. Dengan sistem pencatatan dan pelaporan keuangan yang baik dapat mengetahui laporan hasil usaha dan kondisi UMKM. Selain itu, akuntansi sangat berguna bagi sebuah usaha diantaranya dengan pencatatan secara akuntansi dapat menghasilkan laporan keuangan yang dapat berguna bagi semua pihak. Definisi laporan keuangan yaitu laporan yang menggambarkan dampak keuangan dari transaksi dan peristiwa lain yang diklasifikasikan dalam beberapa kelompok besar menurut karakteristik ekonominya, yaitu kelompok yang berkaitan dengan pengukuran posisi keuangan, kelompok yang berkaitan dengan pengukuran kinerja dan kelompok yang berkaitan dengan pengukuran cash flow, [5] dalam [10].

Informasi akuntansi yang dibutuhkanUMKMsangat minim karena tidak diharuskan menurut undang-undang atau peraturan. Kurangnya kemampuan pelaku UKM dalam bidang pengelolaan usaha juga termasuk kendala yang dihadapi UMKM, 
antara lain rendahnya pendidikan dan kurangnya pemahaman pelaku UKM tersebut dalam bidang akuntansi. [6] menyatakan biasanya pembukuan UKM dilakukan dengan cara-cara sederhana dan tidak detail.

Semakin berkembangnya usaha, menuntut UMKM untuk berhubungan dengan pihak eksternal perusahaan. Misalnya untuk meningkatkan pendanaan UMKM akan berhubungan dengan pihak bank/lembaga keuangan lainnya. Pihak bank/lembaga keuangan tersebut biasanya akan mensyaratkan laporan keuangan untuk menilai kelayakan kredit dari UKM [7].

Penerapan akuntansi Usaha Kecil di Salatiga berdasarkan jenis usaha dagang masih sederhana karena kendala faktor pendidikan yang rendah dalam hal pengetahuan akuntansi dan kurangnya kesadaran akan pentingnya akuntansi [8].

Beberapa penelitian telah dilakukan di Indonesia menunjukkan bahwa praktek akuntansi Usaha Kecil di Indonesia belum berjalan dengan baik [9]. Penelitian dari Kuntati mengatakan bahwa kebutuhan terhadap penerapan akuntansi masih rendah dan banyak responden yang belum pernah mengikuti pelatihan akuntansi[10].

Berdasarkan latar belakang yang peneliti uraikan maka yang menjadi pertanyaan penelitian ini adalah "bagaimana system pencatatan akuntansi pada Usaha Mikro Kecil dan Menengah Kota Baubau?’. Adapun tujuan penelitian ini adalah untuk mengetahui sistem pencatatan akuntansi pada Usaha Mikro, Kecil Dan Menengah di kota Baubau.

\section{METODE PENELITIAN}

Dalam penelitian ini penulis menggunakan pendekatan penelitian deskriptif meliputi pengumpulan data untuk menjawab pertanyaan mengenai status terakhir dari subjek. Maksud dan tujuan pendekatan penelitian deskriptif ini adalah hanya sebatas membuat deskripsi yang tepat, apa adanya tentang fakta-fakta dan sifat-sifat objek tanpa membuat prediksi atau mencari pemecahan masalah yang ada dalam objek tersebut [11].

Penelitian ini dilakukan pada 2 UMKM yaitu Toko Mira dan YDX Bordir. Populasi dalam penelitian ini adalah Usaha Mikro, Kecildan Menengah yang bergerak dibidang perdagangan dan jasa yang adadi kota Baubau.

Sampel dari penelitian ini adalah Usaha Mikro, Kecil dan Menengah yang berada dipertokoan laelangi kota Baubau yaitu Toko Mira dan YDX Bordir,dengan metode pengambilan sampel convenience sampling, yaitu penulis memilih sendiri usaha-usaha mana sajayang akan dijadikan sampel dalam penelitian[12]. 
Pengumpulan data dilakukan melalui observasi yaitu dilakukan dengan cara peninjauan langsung pada objek penelitian untuk mendapatkan informasi dengan membagikan kuisioner. Kuisioner yang diajukan kepada responden berupa daftar pertanyaan tertutup (closed question).

Metode yang digunakan untuk menganalisis data adalah analisis kualitatif dengan tipe deskriptif. Penelitian dengan analisis kualitatif merupakan penelitian yang mempunyai ciri datanya dinyatakan dalam keadaan sewajarnya atau sebagaimana adanya, dengan tidak diubah dalam bentuk simbol-simbol atau bilangan [13]. Tipe penelitian deskriptif bertugas untuk melakukan representasi obyektif mengenai gejala-gejala yang terdapat di dalam masalah penelitian. Adapun tahapan dalam penelitian deskriptif iniadalah:

1. Mengklasifikasikan data berdasarkan pencatatan akuntansi, pelaporan akuntansi dan kendala bisnisnya yang menghambat UMKM dalam penerapan akuntansi yang sudah diperoleh melalui wawancara semi terstruktur dan kuesioner.

2. Mengidentifikasikan pencatatan dan pelaporan akuntansi dari setiap klasifikasi.

3. Menganalisis kendala-kendala yang dihadapi UMKM dalam penerapan akuntansi.

4. Mengolah data dan membuat kesimpulan secara menyeluruh berdasarkan data yang diperoleh.

\section{HASIL DAN PEMBAHASAN}

\section{a. Hasil Penelitian}

\section{Penerapan Akuntansi}

Berdasarkan pertanyaan yang diajukan kepada responden mengenai pencatatan yang mereka lakukan, berikut hasil yang diperoleh dan disajikan dalam bentuk tabel di bawah ini:

Tabel 1. Transaksi yang dicatat oleh Pengelola Usaha

\begin{tabular}{|l|l|c|c|c|c|}
\hline \multirow{2}{*}{ No } & Transaksi yang & \multicolumn{2}{|c|}{ Toko Mira } & \multicolumn{2}{c|}{ Bordir YDX } \\
\cline { 3 - 6 } & & Mencatat & $\begin{array}{c}\text { Tidak } \\
\text { Mencatat }\end{array}$ & Mencatat & $\begin{array}{c}\text { Tidak } \\
\text { Mencatat }\end{array}$ \\
\hline 1 & Penjualan & $\checkmark$ & & $\checkmark$ & \\
\hline 2 & Pembelian & $\checkmark$ & & $\checkmark$ & \\
\hline 3 & Persediaan & & $\checkmark$ & & $\checkmark$ \\
\hline 4 & Kas Masuk & & $\checkmark$ & $\checkmark$ & \\
\hline 5 & Kas Keluar & & $\checkmark$ & $\checkmark$ & \\
\hline 6 & Biaya Gaji & & $\checkmark$ & & $\checkmark$ \\
\hline 7 & Biaya Lain-Lain & & $\checkmark$ & & $\checkmark$ \\
\hline
\end{tabular}

Sumber : Data (diolah) 2017 
Dari tabel 1 terlihat bahwa pada Toko Mira dan Bordir YDX transaksi penjualan dan pembelian sama-sama dicatat. Responden beranggapan bahwa dengan mencatat penjualan, maka dapat langsung mengetahui berapa jumlah pendapatan selama 1 hari, sebagai bukti bahwa penjualan benar-benar terjadi, untuk mencocokkan dengan kas masuk Responden mencatat pembelian sebagai bukti berapa kas yang telah dikeluarkan dan hutang yang masih harus dibayar untuk dicocokkan dengan barang yang telah dibeli. Kas masuk dan kas keluar juga banyak dicatat, karena dari kas masuk dan kas keluar dapat melihat seberapa besar untung ruginya, juga dapat mengontrol pendapatan dan pengeluaran setiap hari.

Persediaan sering dicatat karena untuk mengetahui kapan harus membeli barang jika persediaan hampir habis. Transaksi biaya gaji jarang dicatat. Hal ini disebabkan karena biaya gaji untuk karyawan tidak mengalami perubahan yang signifikan untuk setiap bulannya sehingga mereka mudah mengingat dan juga karena jumlah karyawan yang sedikit. Biaya lain-lain (listrik, air, telepon) jarang dicatat karena sudah ada bukti pembayaran. Persediaan pada perusaahaan jasa jarang dicatat karena persediaan sering digunakan sehingga tidak terlalu penting untuk dicatat.

Periodisasi pencatatan yang dilakukan pengelola Usaha Kecil ditunjukkan oleh tabel di bawah ini:

Tabel 2. Periodisasi Pencatatan

\begin{tabular}{|c|c|c|c|c|c|c|c|c|c|c|c|c|c|c|}
\hline \multirow[t]{2}{*}{ Periodisasi } & \multicolumn{2}{|c|}{ Penjualan } & \multicolumn{2}{|c|}{ Pembelian } & \multicolumn{2}{|c|}{ Persediaan } & \multicolumn{2}{|c|}{ Kas Masuk } & \multicolumn{2}{|c|}{ Kas Keluar } & \multicolumn{2}{|c|}{ Biaya Gaji } & \multicolumn{2}{|c|}{ Biaya Lain-Lain } \\
\hline & $\begin{array}{l}\text { Toko } \\
\text { Mira }\end{array}$ & $\begin{array}{l}\text { Bordir } \\
\text { YDX }\end{array}$ & $\begin{array}{l}\text { Toko } \\
\text { Mira }\end{array}$ & $\begin{array}{l}\text { Bordir } \\
\text { YDX }\end{array}$ & $\begin{array}{l}\text { Toko } \\
\text { Mira }\end{array}$ & $\begin{array}{l}\text { Bordir } \\
\text { YDX }\end{array}$ & $\begin{array}{l}\text { Toko } \\
\text { Mira }\end{array}$ & $\begin{array}{l}\text { Bordir } \\
\text { YDX }\end{array}$ & $\begin{array}{l}\text { Toko } \\
\text { Mira }\end{array}$ & $\begin{array}{l}\text { Bordir } \\
\text { YDX }\end{array}$ & $\begin{array}{l}\text { Toko } \\
\text { Mira }\end{array}$ & $\begin{array}{l}\text { Bordir } \\
\text { YDX }\end{array}$ & $\begin{array}{l}\text { Toko } \\
\text { Mira }\end{array}$ & $\begin{array}{l}\text { Bordir } \\
\text { YDX }\end{array}$ \\
\hline Tiap Hari & $J$ & J & & & $J$ & $J$ & J & J & J & $J$ & & & & \\
\hline $\begin{array}{l}\text { Tiap } \\
\text { Minggu }\end{array}$ & & & & & & & & & & & & & & \\
\hline Tiap Bulan & & & J & J & & & & & & & J & J & & \\
\hline Lain-Lain & & & & & & & & & & & & & $\sqrt{ }$ & J \\
\hline
\end{tabular}

Sumber : Data (diolah) 2017

Dari Tabel 2 dapat diketahui bahwa penjualan, kas masuk, dan kas keluar dicatat setiap hari. Yang perlu diperhatikan adalah pembelian yang berkaitan dengan catatan persediaan. Pembelian dilakukan saat barang yang dijual habis dan periodisasinya tidak ditentukan dengan pasti karena bergantung dengan jumlah barang yang masih tersedia. Hal ini menunjukkan bahwa catatan mengenai jumlah persediaan sangat 
dibutuhkan untuk memperlancar bisnis yang dijalankan. Oleh karena itu, maka persediaan sering dicatat untuk mengetahui kapan harus membeli barang jika persediaan hampir habis.

Biaya gaji jarang dicatat. Hal ini disebabkan karena biaya gaji untuk karyawan tidak mengalami perubahan yang signifikan untuk setiap bulannya sehingga mereka mudah mengingat dan juga karena jumlah karyawan yang sedikit.

\section{Pelaporan}

Pelaporan yang dibuat usaha kecil, antara lain:

Tabel 3.Pelaporan yang Dibuat Pengelola Usaha

\begin{tabular}{|l|c|c|c|c|}
\hline \multirow{2}{*}{$\begin{array}{l}\text { Laporan yang Dibuat } \\
\text { Pengelola }\end{array}$} & \multicolumn{4}{|c|}{ Membuat Laporan } \\
\cline { 2 - 5 } & Toko Mira & \multicolumn{2}{c|}{ Bordir YDX } \\
\cline { 2 - 5 } & Membuat & Tidak & Membuat & Tidak \\
\hline Laporan Penjualan & & $\checkmark$ & $\checkmark$ & \\
\hline Laporan Pembelian & & $\checkmark$ & $\checkmark$ & \\
\hline Laba/Rugi & & $\checkmark$ & $\checkmark$ & \\
\hline Perubahan Ekuitas & & $\checkmark$ & & $\checkmark$ \\
\hline Neraca & & $\checkmark$ & & $\checkmark$ \\
\hline
\end{tabular}

Sumber : Data (diolah) 2017

Berdasarkan Tabel 3 dapat disimpulkan bahwa tidak semua responden yang melakukan pencatatan juga membuat laporan. Terbukti bahwa pada Toko Mira tidak membuat laporan penjualan, laporan pembelian, laba/rugi, perubahan ekuitas dan neraca. Toko Mira tidak membuat laporan keuangan karena usaha dikelola sendiri, usaha masih sederhana sehingga tidak perlu membuat laporan, dari nota penjualan dan pembelian, kas masuk, juga kas keluar sudah tahu apakah usahanya laba atau rugi. Pada Bordir YDXhanya membuatlaporan penjualan, laporanpembelian dan laba/rugi sedangkan perubahan ekuitas dan neraca tidak dibuat.

Laporan penjualan, laporan pembelian dan laba/rugi yang dibuat menggambarkan bahwa laporan yang mereka buat mencerminkan tujuannya yaitu untuk keperluan internal manajemen dalam usaha mereka. Bordir YDX beranggapan bahwa pada laporan penjualan mereka melihat apakah usahanya telah mengalami kemajuan dalam meningkatkan laba, omzet, dan assetnya untuk perkembangan usahanya, sedangkan laporan pembelian dibuat untuk mengecek barang apa saja yang masih tersedia dan laba/rugi untuk mengetahui adanya laba atau rugi diperoleh dari selisih antara harga penjualan dan pembelian. Jika selisih dari harga penjualan dan 
pembelian positif menunjukan laba, jika selisih dari harga penjualan dan pembelian negatif menunjukan rugi, kalau ada laba berarti modal bertambah dan jika rugi maka modal berkurang, para pengelola tidak mempunyai neraca, tetapi mengetahui kekayaan hanya pada kas dan laporan persediaan.

\section{Tujuan Pembuatan Pelaporan}

Adapun tujuan pembuatan laporan Toko Mira dan Bordir YDX dapat dilihat dari tabel 4 berikut ini :

Tabel 4.Tujuan Pembuatan Laporan

\begin{tabular}{|l|c|c|}
\hline \multirow{2}{*}{\multicolumn{1}{c|}{ Tujuan }} & \multicolumn{2}{c|}{ Responden } \\
\cline { 2 - 3 } & Toko Mira & Bordir YDX \\
\hline Manajemen & - & $\checkmark$ \\
\hline Kredit & - & $\checkmark$ \\
\hline Pajak & - & - \\
\hline Manajemen dan Kredit & - & $\checkmark$ \\
\hline Manajemen dan Pajak & - & - \\
\hline $\begin{array}{l}\text { Manajemen, Kredit dan } \\
\text { Pajak }\end{array}$ & - & - \\
\hline
\end{tabular}

Sumber : Data (diolah) 2017

Tabel 4 menunjukkan bahwa tujuan pelaporan yang dibuat masih sangat sederhana yaitu untuk pengelolaan usaha dan untuk keperluan manajemen usaha sendiri. Untuk Bordir YDX tujuan pembuatan laporan untuk keperluan manajemen dan kredit.

\section{Dokumen yang Dibuat}

Dokumen yang dibuat oleh Usaha Kecil di Baubau, antara lain:

Tabel 5. Dokumen yang Digunakan Pengelola

\begin{tabular}{|l|c|c|}
\hline \multicolumn{1}{|c|}{ Keterangan } & Toko Mira & Bordir YDX \\
\hline Nota Penjualan & $\sqrt{ }$ & $\checkmark$ \\
\hline Nota Pembelian & $\checkmark$ & $\checkmark$ \\
\hline Tidak Membuat Semuanya & - & - \\
\hline Sumber : Data (diolah) 2017 &
\end{tabular}

Dari tabel diatas dapat dilihat bahwa baik Toko Mira maupun Bordir YDX menggunakan nota penjualan dan nota pembelian. Nota penjualan ini digunakan oleh pemilik usaha untuk mengetahui jumlah yang harus dibayar konsumen, bukti jika ada kesalahan pembayaran dan mengetahui berapa kas yang diterima pada tiap transaksi. Nota pembelian digunakan oleh pemilik usaha untuk mencatat persediaan 
yang telah dibeli dan mengetahui berapa banyak kas yang keluar untuk perkembangan usahanya.

\section{b. Pembahasan}

\section{Sistem Pencatatan Reponden}

Untuk mengetahui pencatatan responden, maka penulis menanyakan apa pencatatan secara komputerisasi atau manual yang dapat dilihat dalam tabel di bawahini. Komputerisasi yang dimaksud adalah pemakaian komputer sebagai alat bantu penyelesaian tugas sebagai pengganti penyelesaian secara manual.

\section{Tabel 6. Sistem Pencatatan Responden}

\begin{tabular}{|c|l|c|c|}
\hline No & Keterangan & Toko Mira & Bordir YDX \\
\hline 1 & Komputerisasi & - & $\checkmark$ \\
\hline 2 & Manual & $\boldsymbol{J}$ & - \\
\hline
\end{tabular}

Sumber : Data (diolah) 2017

Dilihat dari tabel 6 tentang sistem pencatatan, Bordir YDX menggunakan sistem pencatatan secara komputerisasi. Sedangkan Toko Mira masih menggunakan sistem pencatatan secara manual, Toko Mira masih menggunakan pencatatan secara manual karena penggunaan komputer yang rumit dan usaha masih dikelola sendiri jadi cukup dengan menggunakan kalkulator.

\section{Pelatihan Akuntansi}

Pelatihan akuntansi yang dimaksud adalah pelatihan akuntansi yang diselenggarakan oleh suatu lembaga pendidikan luar sekolah maupun lembaga pendidikan tinggi, atau balai pelatihan departemen atau dinas tertentu. Berikut data yang menyatakan pernah mengikuti pelatihan akuntansi dan belum pernah mendapat pelatihan akuntansi:

Tabel 7. Pelatihan Akuntansi

\begin{tabular}{|c|l|c|c|}
\hline No & \multicolumn{1}{|c|}{ Keterangan } & Toko Mira & Bordir YDX \\
\hline 1 & Pernah Ikut & - & - \\
\hline 2 & Tidak Pernah Ikut & $\boldsymbol{J}$ & $\checkmark$ \\
\hline
\end{tabular}

Sumber : Data (diolah) 2017

Dari tabel 7 terlihat baik Toko Mira maupun Bordir YDX tidak pernah mengikuti pelatihan akuntansi. Dari hasil wawancara alasan tidak pernah mengikuti pelatihan 
akuntansi karena tidak pernah mendapat informasi tentang adanya pelatihan tentang akuntansi baik dari pemerintah maupun swasta.

\section{Kendala}

Beberapa kendala yang dihadapi oleh Usaha Mikro, Kecil dan Menengah sehingga mereka tidak menerapkan akuntansi adalah karena minimnya pengetahuan tentang pencatatan akuntansi dan kurangnya kesadaran akan pentingnya akuntansi dalam suatu bisnis yang mereka jalankan terbukti dari rendahnya tingkat kebutuhan akuntansi. Bagi beberapa perusahaan yang usahanya dimiliki sendiri, punya kecenderungan berpikir hanya sebatas "bisa memenuhi kebutuhan hidup keluarga" menjadi gaya hidup yang menghambat berkembangnya perusahaan (sumber: wawancara dengan Bapak $\mathrm{H}$. Muhsin Alwan 10 September 2017 jam 11:15 WITA).

Berikut data yang menyatakan tingkat kebutuhan pelatihan akuntansi:

Tabel 8. Kebutuhan Pelatihan Akuntansi

\begin{tabular}{|c|l|c|c|}
\hline No & Keterangan & Toko Mira & Bordir YDX \\
\hline 1 & Butuh & $\boldsymbol{J}$ & $\checkmark$ \\
\hline 2 & Tidak Butuh & - & - \\
\hline
\end{tabular}

Sumber : Data (diolah) 2017

Dari tabel 8 diatas baik Toko Mira maupun Bordir YDX membutuhkan pelatihan akuntansi.Dari usaha yang diteliti, responden tidak membuat pencatatan dengan alasan usaha tersebut masih sederhana, dikelola sendiri, dan hanya untuk memenuhi kebutuhan keluarga sehingga mereka tidak melakukan pencatatan dan pelaporan.Keterbatasan ilmu tentang akuntansi mempengaruhi keputusan pengusaha untuk menerapkan pencatatan akuntansi.

Pemilik Toko Mira dan Bordir YDX yang sudah lama mendirikan usaha lebih nyaman melakukan pencatatan berdasarkan pengalaman. Keterbatasan inilah yang membuat mereka kurang mampu mengadakan perencanaan, pencatatan dan pelaporan.

\section{KESIMPULAN}

Dari hasil penelitian yang diuraikan di atas dapat disimpulkan bahwa Toko Mira dan Bordir DYXmewakili UMKM Kota Baubau sebenarnya sudah menerapkan akuntansi secara sederhana seperti melakukan pencatatan penjualan, pembelian, persediaan, kas masuk, kas keluar, biaya gaji dan biaya lain-lain. Namun akuntansi yang diterapkan 
belum optimal, yaitu dari membuat pencatatan sampai dengan pelaporan. Hal ini disebabkan oleh beberapa faktor kendala yang dihadapi yaitu: (1) minimnya pengetahuan tentang pencatatan akuntansi; dan (2) kurangnya kesadaran terhadap pentingnya akuntansi terbukti dari rendahnya tingkat kebutuhan akuntansi.

\section{SARAN}

Dilihat dari kesimpulan diatas maka penulis menyarankan dalam penelitian ke depan sebaiknya bersama-sama dengan pemerintah kota dalam hal ini khususnya dinas koperasi mengadakan penelitian ini secara mendalam terhadap UMKM. Dari informasi yang terkumpul digunakan untuk memberikan pelatihan akuntansi kepada para UMKM. Hasilnya diharapkan akan sama- sama menguntungkan antara UMKM dan pemerintah.

\section{DAFTAR PUSTAKA}

[1] Primiana, Ina. 2009. Menggerakkan Sektor Riil UKM \& Industri.Bandung: Alfabeta.

[2] Sony Warsono. 2010. Akuntansi UMKM Ternyata Mudah Dipahami dan Dipraktikan. Yogyakarta: Asgard Chapter.

[3] Martani, Dwi. 2011. Standar Akuntansi Keuangan Entitas Tanpa Akuntabilitas Publik (SAK-ETAP).Diakses pada 30 November 2017 dari http://staff.blog.ui.ac.id

[4] Ikatan Akuntan Indonesia. 2007. Standar Akuntansi Keuangan. Jakarta: Salemba Empat.

[5] Endif. 2009. Penerapan Akuntansi untuk UMKM.

[6] Krisdiartiwi. 2008. Pembukuan Sederhana untuk UKM. Yogyakarta: MedPress

[7] Soemarno S.R 2004. Profil Usaha Kecil Menengah (UKM) di Jawa Tengah, Jurnal Fakultas Ekonomi Ekonomi.

[8] Warren,CarlS.,JamesReevedanPhilipE. Fees. 2006. Pengantar Akuntansi.Edisi Dua Puluh Satu.Jakarta: SalembaEmpat.

[9] Suhairi. 2008. Overload Standar Akuntansi Keuangan (SAK), dan analisis Teknik Serta Prosedur Akuntansi Untuk Pengembangan Penerapan Akuntansi pada Usaha Kecil dan Menengah (UKM) di Indonesia. Working Paper. Fakultas Ekonomi Universitas Andalas. Unpublished.

[10] Kurniawati, E. P., P. I. Nugroho, dan D. Setiawati. 2010.Penerapan Akuntansi Untuk Usaha Kecil dan Menengah (UKM) Studi Kasus Pada Usaha Dagang Kota Salatiga.Jurnal Manajemen dan Keuangan. Volume 10 Nomor 2.

[11] Astutidan Widiatmoko 2003. Profil Usaha Kecil Menengah (UKM) di Jawa 
Tengah.Jurnal Fokus Ekonomi. Volume 2 (3): 215 - 228.

[12] Tunggal, Amin Widjaja. 2009.Akuntansi Untuk Perusahaan Kecil dan Menengah. Jakarta: PT Rineka Cipta.

[13] Sinulingga Sukaria. 2012. Metode Penelitian. Edisi Kedua. Medan: USU Press 